\title{
A COOPERATIVE PRINCIPLE: GRICEAN MAXIM ANALYSIS UPON A JAPANESE LIGHT NOVEL OF ‘SHŪMATSU NANI SHITEMASU KA? ISOGASHII DESU KA? SUKUTTE MORATTE II DESU KA?"
}

\author{
Vidya Mandarani, Nur Muhammad Ardiansyah \\ Universitas Muhammadiyah Sidoarjo \\ vmandarani@umsida.ac.id,ardiansyah.nurmuhamad@gmail.com
}

\begin{abstract}
This article describes the study of discourse analysis in a specified domain of maxim upon a selected work of Japanese literature, in form of light novel written by Akira Kareno and illustrated by Ue, entitled equals in English as 'What Do You Do at the End of the World? Are You Busy? Will You Save Us?'. Several objectives are deduced by the researcher in quest of finding the forms of these cooperative principles within the passage. Briefly, maxim itself is a maxim is a compact expression of a general truth or rule of conduct. Also known as a proverb, saying, adage, sentential, and precept, which emphasized the use of formulaic ways of conveying the common wisdom of the people. In our analysis of 'WorldEnd' light novel, the varieties of Gricean maxim: maxim of quantity, quality, relevance, and manner, are discussed in order in relation with true meaning discovery behind each cooperative principles properties.
\end{abstract}

Keyword : Discourse Analysis, Cooperative Principles, Gricean Maxim, Japanese Literature, Light Novel, SukaSuka.

\section{Introduction}

Language as the sole medium for human to communicate one to another has transcended into a complex systematic mechanism where one could produce an utterance as an attempt to convey an information or message towards his/her readers or listeners. Pragmatics is a study about the meaning from the speaker to the hearer (Yule, 1996).

Leech (1983: 1) states that pragmatics is the study of the meaning of speech in every situations. Thereby, throughout the eras has gradually changed by major factors, which most of these heavily related with societal cultures. One of the acknowledged outcome of it, such literature, is no exception for this alteration. Human literation also reformed all over centuries in many cases found by historian and linguist alike. Each group of civilization boast their peculiar traits of literacy characteristic, which is rather distinctive one to another. Japan is no exception for this continuing change. Starting with the renowned Heian period masterpiece 'The Tale of Genji' until the nowadays era of literature was also heavily influenced by intercultural values. Since the Meiji restoration, Japan literacy style was somehow mingled by westernised and euro- centric style that later also assists toward the emboldening identity of neo-modernism. Many-famed product of Japanese literature is highly valued by many readers or just a cultural connoisseur. Light novel is one of the examples. Meanwhile, as literature is also formed by an utterance in a language, it is essential to relates such emerges with the importance of discourse analysis as the generalized discipline that has the authoritative endeavour to investigate as well as observes the way an utterance used in accordance with discourse philosophies and the use of linguistic functions in each works.

Light novel is an entire different type of written literature product. Compared to its full novel as most people aware, light novel, is a kind of Japanese novel that primarily made and targeting consumers ranging from teenagers to young adults. Its unique demographic and peculiar printing medium signifies the role of light novel as the representation of the growth of Japanese literature. Meanwhile, due to its ridiculously long name, hence researcher decided to abbreviate the light novel's title into 'SukaSuka' onwards. The title, which is published by Yen Press for its English translation earned a reputable hits during its first 
launch in the early of 2016. The story revolves around mysterious man who lost everything in his final battle five hundred years ago, and had awakened from a long, icy slumber only to find that his human race went extinct, while the remaining humanoid races barely survived by creating a last aerial bastion, the sky islands. It has rather dubious yet somehow tragic ending in the end. The title of this light novel itself has already adapted into Manga and Anime.

To sum it short, it is a communicative principle that firstly proposed by Herbert Paul Grice as an elaboration to his cooperative principles, hence the name. The theory signifies either that a speaker, who is assumed cooperative, can be understood as meaning, more than he literally says, by succeeding the maxim or by violating it (explained further in the following sub-topic). Despite of the breakthrough in world of linguistic, many citizen that Grice's theory cannot be implemented in all situational conversation, moreover when it includes cultural diversities that is peculiar and different compared to Grice's cultural parameter. For instance, cooperative principles often embodying straightforwardness, while there are cultures, which emphasized its opposite. It is worth mentioned that Aristotle observed that a maxim might also serve as the premise or conclusion of an enthymeme.

Grice describes cooperation as involving four maxims: quantity, quality, relation, and manner. Grice proposes four maxims expected in conversation. The first is quality maxims, the speaker explains the truth or provable use evidence in the conversation. The second is quantity maxims, the speaker is as informative as required to deliver the message. The third is relation maxims, the response is relevant to topic of conversation. The fourth is manner maxims, the speaker's avoids ambiguity or obscurity, the way to deliver the purpose of speaking is direct and straightforward to the topic. Levinson (1985) explains that the cooperative principle by Grice is a theory related to communication; it has the consequence of how communication might be reached in the absence of any conventional means for expressing the message.

\section{Research Methodology}

Researcher is fully aware that within this case, a thorough textual analysis is the most favourable investigation approach by consid- ering the task and medium of the research, compared to the other methodologies. Hancock (2007) describes that qualitative research is focused with developing explanation from the phenomena.The outcomes are expected to be generalizable, valid, and steadfast by scientific perspective. In order to conduct the research, researcher first will have to read the whole passage as an effort of 'cooperative principles scanning' that later will ease researcher in identifying which types used and which are not. As a careful attempt, a second read by using extensive reading will do the work of optimizing the accuracy of the previous highlights. Then, researcher will validate his reasoning in selecting the highlighted Gricean maxims with the existing theory from the previously mentioned major reference. In the end, the finding will be discussed in the following sub-chapter.

\section{Finding and Discussion}

During the investigation, researcher found some evidences of Gricean maxim elements within the light novel. Later in this subchapter, researcher will describe in detail regarding on the reason in choosing the specified parts of conversation as the representative of the particular cooperative principles basics mentioned in the previous sub-chapter. Here is the detail:

\section{Maxim of Quality}

First type of cooperative principle invented by Grice is the quality maxim, which as clearly emphasized by its name, this maxim concerns into the 'quality' of a communication in term of truthfulness, and strong assertion as the respond in each communication, as exemplified in the following conversation:

\begin{tabular}{|l|l|l|}
\hline Ali & $: \begin{array}{l}\text { So, you are going to choose the this } \\
\text { faculty for your study, aren't you? }\end{array}$ \\
\hline Ane & $: \begin{array}{l}\text { I have carefully think about it several } \\
\text { times, and yes, I'm certain of it. }\end{array}$ \\
\hline
\end{tabular}

Prior to the above sample, here the evidence of quality maxim existed within the light novel, as cited: 
As well as another example as follows:

\begin{tabular}{|l|l|}
\hline Men & $: \begin{array}{l}\text { Anyway, I'm here now, and where } \\
\text { those people chose to go has nothing } \\
\text { to do with me. }\end{array}$ \\
\hline Girl & $\begin{array}{l}\text { So you don't have any girl you want to } \\
\text { spend your last night with, Father? }\end{array}$ \\
\hline Men & $\begin{array}{l}\text { There is no way I'd have that kind of } \\
\text { free time. Ever since I qualified to be- } \\
\text { come a Quasi Brave, everyday has } \\
\text { been never-ending training, studying, } \\
\text { fighting, and more fighting! }\end{array}$ \\
\hline
\end{tabular}

These proofs displayed the most basic parts of maxim, where a question is answered by its preferred counter-response.

\begin{tabular}{|l|l|}
\hline Girl & $: \begin{array}{l}\ldots \text { so, why did you come back } \\
\text { here? }\end{array}$ \\
\hline Man & $: \begin{array}{l}\text { I just told you, didn't I? Tomorrow } \\
\text { is the final battle. There's no guar- } \\
\text { antee that we'll be able to come } \\
\text { home safely, so they said to spend } \\
\text { our last night with the people im- } \\
\text { portant to us- }\end{array}$ \\
\hline
\end{tabular}

\begin{tabular}{|l|l|l|}
\hline Man & $:$ & Are the little kids already in bed? \\
\hline Girl & $: \begin{array}{l}\text { Of course. What time do you think } \\
\text { it is? }\end{array}$ \\
\hline
\end{tabular}

\section{Maxim of Quantity}

While quality prefers the strength factors of one argument to uphold, quantity maxim only concerns with the informativeness of an utterance. Generally, it shows that this maxim encourages speaker or writer to tries as explanatory as possible and gives as much information as is needed, no more or less or equally precise in proportion. Here is the illustration:

In most cases, we usually assume that people are telling us everything we need to know. If they do not say something, then we assume they simply do not know that infor-

\begin{tabular}{|l|l|l|}
\hline Nia & $: \begin{array}{l}\text { You know, Lia is able to pass the Todai } \\
\text { University entrance exam! }\end{array}$ \\
\hline Ely & $: \begin{array}{l}\text { Whoa really? Just how far did she put } \\
\text { her efforts to? }\end{array}$ \\
\hline Nia & $: \begin{array}{l}\text { She ever mentioned that she studied } \\
\text { for a month long without breaks! }\end{array}$ \\
\hline
\end{tabular}

mation. It is worth noted that the kind of maim violation within this case will often cause misinformation. Now, here is sample found within the light novel:

Though at first, the man's answer seemed out of the preferred answer, his utterance implies that due to his busy activities, he did not have any time to look for a girlfriend.

\section{Maxim of Relevance}

The idea of essential point that this kind of maxim highlights is whether a form of conversation indeed contains utterances (regardless the subject) that are relevant to the topic under discussion. Here is the slight example on how Relevance Maxim works in a conversation:

According to the following sample, researcher highlighted several parts of conversation, which supposed for having relevance maxim, as follows:

\section{Maxim of Manner}

Researcher considered this type of cooperative principles is the most difficult maxim to be defined since the qualifications involve of the clarity, briefness, and orderly con-

\begin{tabular}{|l|l|}
\hline Joe & $: \begin{array}{l}\text { Is Abigail dating anyone these } \\
\text { days? }\end{array}$ \\
\hline Zoe & $: \begin{array}{l}\text { Well, seems so, since she goes to } \\
\text { town square every weekend. }\end{array}$ \\
\hline
\end{tabular}

structed while should avoid obscurity and ambiguity in the same time. We should not use words you know your listeners will not understand, say things that you know could

\begin{tabular}{|l|l|}
\hline Girl & $: \begin{array}{l}\text { But still, at least in times like these, } \\
\text { don't you think you could say } \\
\text { something a little considerate for } \\
\text { once? }\end{array}$ \\
\hline Man & $\begin{array}{l}\text { Something considerate? Like } \\
\text { what? }\end{array}$ \\
\hline Girl & $: \begin{array}{l}\text { 'After this war ends, I'll get mar- } \\
\text { ried!' Something like that. }\end{array}$ \\
\hline
\end{tabular}

be misunderstood, and state events briefly and following the natural order of events. 
As exemplified by the following example:

\begin{tabular}{|l|l|l|}
\hline Lia & $:$ & $\begin{array}{l}\text { I hear you went to the opera last } \\
\text { night; how was the lead singer? }\end{array}$ \\
\hline Sam & $:$ & $\begin{array}{l}\text { The singer produced a series of } \\
\text { sounds corresponding closely to } \\
\text { the score of an aria from } \\
\text { 'Rigoletto'. }\end{array}$ \\
\hline
\end{tabular}

Based on the following sample, researcher implied that the conversation informs the clear and unambiguous description of a certain singer. In comparison, researcher also found the following mark of manner maxim:

The example indicates that the girl an-

\begin{tabular}{|l|l|}
\hline Man & $: \begin{array}{l}\text { Then what about that good-for- } \\
\text { nothing master? }\end{array}$ \\
\hline Girl & $: \begin{array}{l}\text { He said he had some business in the } \\
\text { Capital and went off. Lately when- } \\
\text { ever I think he has come home, he } \\
\text { goes right out the door again. I wish } \\
\text { he would just settle down here for a } \\
\text { while. }\end{array}$ \\
\hline
\end{tabular}

swer the man's curiosity of the good-fornothing master's whereabouts in detail and clear as well as unequivocal, though added by a slight wish in her end of utterance.

Grice (1989) presents cooperative principle theory to make our conversation contributions such as is required at the stage at which it occurs, by the accepted purpose or direction of the talk exchange in which we are engaged. This statement in line with Mandarani research Cooperative principle still can be reached although not all the maxims use in conversation between the vendors of Borobudur Temple and Foreign Tourists. In this novel the use of four maxims, indicates that the author use cooperative principle in expressing the meaning in the novel.

\section{Conclusion}

After several examination upon the short story in regard with the practicality of cooperative principles, researcher hereby deduces that the work composed by the author, Akira Kareno, and illustrated by Ue, indeed contains several attributes known as the items of Gricean maxims within the study of discourse analysis, as mentioned in the previous sub-chapters. These features indeed enrich the depth of the plot by involving human's imagi- native and surrealistic sense of conversation to reach the cooperative principle in the novel's conversation.

\section{Reference}

Grice P, (1989). Studies in the Way of Word. Cambridge: Harvard University Press.

Hancock, B,. Windridge K., and Ockleford E. (2007). An Introduction to Qualitative Research. East Midlands: The NIHR RDS $\mathrm{EM} / \mathrm{YH}$.

Leech, Geoffrey. (1983). The Principle of Pragmatics. London: Longman Group UK. Limited.

Levinson, Stephen C. (1985). Pragmatics. Cambridge: Cambridge University Press.

Mandarani, V. (2017). Cooperative Principle used by the Vendors of Borobudur Temple In Communication with the Foreign Tourists. KnE Social Sciences. Volume 1 (3). pp 319325.

Yule G, (1996). Pragmatics. Oxford: Oxford University Press. 